\title{
Vegetative growth, compatible solute accumulation, ion partitioning and chlorophyll fluorescence of 'Malas-e-Saveh' and 'Shishe-Kab' pomegranates in response to salinity stress
}

\author{
M. KHAYYAT ${ }^{*,+}$, A. TEHRANIFAR ${ }^{*}$, G.H. DAVARYNEJAD*, and M.H. SAYYARI-ZAHAN ${ }^{* *}$ \\ Department of Horticultural Science, College of Agriculture, Ferdowsi University of Mashhad, Mashhad, Iran* \\ Department of Soil Science, College of Agriculture, University of Birjand, Birjand, South Khorassan, Iran ${ }^{* *}$
}

\begin{abstract}
The present research was conducted to assess physiological responses of 'Malas-e-Saveh' (Malas) and 'Shishe-Kab' (Shishe) pomegranates to water of different salt content and electrical conductivity $\left(1.05,4.61\right.$, and $7.46 \mathrm{dS} \mathrm{m} \mathrm{m}^{-1}$ ). Both cultivars showed a reduced trunk length due to salinity. Relative water content and stomatal conductivity of both cultivars were significantly reduced under salt stress, but ion leakage increased. In both cultivars, total chlorophyll (Chl) and carbohydrates decreased with rise in salinity, while proline accumulation increased. With salinity increment, the Chl fluorescence parameters (maximum photochemical efficiency of PSII and effective quantum yield of PSII) declined significantly in both cultivars, with higher reduction observed in Shishe. Generally, more $\mathrm{Na}^{+}$accumulated in shoots and more $\mathrm{Cl}^{-}$was observed in leaves. $\mathrm{Cl}^{-}$accumulation increased by salinity in leaves of Malas, but it was reduced in Shishe. The $\mathrm{K}^{+} / \mathrm{Na}^{+}$ratio in leaves decreased in both cultivars by salinity increment. Malas was less affected by osmotic effects of $\mathrm{NaCl}$, but it accumulated more $\mathrm{Cl}^{-}$in its leaves. Thus, Malas might be more affected by negative effects of salinity.
\end{abstract}

Additional key words: chloride; fluorescence; growth; $\mathrm{NaCl}$; potassium; proline; sodium; total carbohydrates.

\section{Introduction}

Pomegranate (Punica granatum L., Punicaceae) is an important horticultural crop for both domestic and export markets in Iran. It has been cultivated widely in arid and semiarid regions that face salinity stress (Ranjbar 1981, Khoshgoftarmanesh and Siadat 2002). Nowadays, comercial orchards of pomegranate trees can be seen in the Mediterranean basin and Asia (Holland et al. 2009). Of the current 230 million ha of irrigated land, 45 million ha $(20 \%)$ are affected (FAO 2008) by primary and/or secondary salinity (Chapman 1966). Primary salinity arises from weathered rocks, capillary rise from shallow brackish groundwater, salt laden sand blown by sea winds, and impeded drainage. Secondary salinization is the result of human activities, such as fields irrigated without proper drainage system, industrial effluents, excessive lands with natural plant cover removed, flooding with salt-rich waters, high water table, and irrigation with poor-quality groundwater (Mane et al. 2011). Under salinity stress, plant growth and development is affected negatively by water stress (i.e., by lowering osmotic potential of soil solution and thus reducing water uptake) or by ionic stress (i.e., by nutritional imbalance and/or toxicity), or by the combination of the mentioned factors (Ashraf 1994, Marschner 1995, Ashraf and Harris 2004, Silva-Ortega et al. 2008). Water stress results from high solute concentration, while ionic stress relates to altered $\mathrm{Na}^{+} / \mathrm{K}^{+}$ and $\mathrm{Na}^{+} / \mathrm{Ca}^{2+}$ ratios or high, harmful $\mathrm{Na}^{+}$and $\mathrm{Cl}^{-}$ concentrations (Apse and Blumwald 2007). Nutrient

Received 26 May 2013, accepted 30 September 2013.

${ }^{+}$Corresponding author email: mhdkhayat@Birjand.ac.ir

Abbreviations: ABA - abscisic acid; C - control; Chl - chlorophyll; DM - dry mass; EC - electrical conductivity; $\mathrm{F}_{0}$ - the minimal fluorescence in the dark-adapted state; $\mathrm{Fe}$ - iron; $\mathrm{F}_{\mathrm{m}}$ - the maximal fluorescence in the dark-adapted state; $\mathrm{FM}$ - fresh mass; $\mathrm{F}_{\mathrm{s}}-$ minimum $\mathrm{Chl}$ fluorescence in the light-adapted state; $\mathrm{F}_{\mathrm{v}}$ - the variable fluorescence; $\mathrm{F}_{\mathrm{v}} / \mathrm{F}_{\mathrm{m}}$ - maximum PSII photochemical efficiency; $\mathrm{F}_{\mathrm{m}}{ }^{\prime}-$ maximum $\mathrm{Chl}$ fluorescence in the light-adapted state; $g_{\mathrm{s}}$ - stomatal conductance; LIL - leaf ion leakage; Malas - Malas-e-Saveh; $\mathrm{qN}_{\mathrm{N}}$ - nonphotochemical quenching; qP - photochemical quenching; RWC - relative water content; $\mathrm{S} 1-\mathrm{EC}$ of $4.61 \mathrm{dS} \mathrm{m}^{-1} ; \mathrm{S} 2-\mathrm{EC}$ of $7.46 \mathrm{dS} \mathrm{m}^{-1}$; Shishe - Shishe-Kab; SLA - specific leaf area; SLM - specific leaf mass; SSP - soil-saturated paste; TD - trunk diameter; TL - trunk length; TM - turgid mass; $\Phi_{\text {PSII }}$ - effective quantum yield of photochemical energy conversion in PSII.

Acknowledgments: We gratefully acknowledge Farid Moradinezhad, Alireza Samadzadeh, Yasin Helalbeigi, and Masoud Khazaee for their capable technical assistance.

(C) The Author(s). 2014 This article is published with open access at link.springer.com 
uptake can be affected by $\mathrm{Na}^{+}$and $\mathrm{Cl}^{-}$ions through competition or changing membrane selectivity, e.g., high concentration of $\mathrm{Na}^{+}$increases potassium and/or calcium deficiency (Tester and Davenport 2003). Munns and Tester (2008) defined salinity resistance as the ability to maintain adequate growth and metabolism under stress. Paranychianakis and Angelakis (2008) reported that distinction between salt-tolerant and -sensitive genotypes is associated with mechanism of ion uptake and accumulation patterns into different organs. Smekens and Vantienderen (2001) showed that salt treatments result in thicker leaves and higher leaf dry matter. In glycophytes, such as citrus and rose, $\mathrm{NaCl}$ stress symptoms are observed in lower leaves and they are distributed to upper ones after salinity increment (Banuls and Primo-Millo 1995, Weber and Reimann-Phillip 1989). Wahome (2003) reported that plants may loose some sections of their shoots under such conditions. Bongi and Loreto (1989) showed that photosynthesis is reduced partly because of the reduced mesophyll conductance caused by leaf thickening in saltstressed olive leaves. The cortex/stele ratio in olive plants increased under salinity because of water deficit (Karimi et al. 2009). Marschner (1995) stated that plant species differ greatly in their growth response to salinity, thus they can be categorized into two groups: (1) halophytes grow optimally at relatively high $\mathrm{NaCl}$ concentration $(400 \mathrm{mM})$, and (2) glycophytes show relatively low salt tolerance and their growth is severely inhibited even at low salinity levels. Plants adopt 3 physiological strategies to cope with excessive amounts of $\mathrm{Na}^{+}$and $\mathrm{Cl}^{-}$in the root medium: $(a)$ osmotic stress tolerance, $(b) \mathrm{Na}^{+}$and $\mathrm{Cl}^{-}$exclusion from leaves, and (c) tissue tolerance to $\mathrm{Na}^{+}$and $\mathrm{Cl}^{-}$ accumulation (Zhu 2003, Estan et al. 2005, Munns et al. 2006, Ashraf and Foolad 2007, Molinari et al. 2007, Martinez-Rodriguez et al. 2008, Munns and Tester 2008). Thus, plants respond to salinity at nonstomatal and/or stomatal levels. Nonstomatal responses include instability of pigment-protein complexes and destruction of chloroplast structure (Zaman et al. 2002), which inhibits photosynthetic activities (Matos et al. 2004, Rouhi et al. 2006). At the stomatal level, the stomatal activity is

\section{Materials and methods}

Plants, growth conditions, and treatments: The research was carried out using one-year-old, bare rooted pomegranate plants of Malas and Shishe cultivars under the field conditions at Salinity Research Station of University of Birjand $\left(32^{\circ} 52^{\prime} \mathrm{N}\right.$ and $\left.52^{\circ} 12^{\prime} \mathrm{E}\right)$. During 2011 and 2012, annual precipitation was $c a .171 \mathrm{~mm}$, the lowest and the highest temperatures were -5 and $+40^{\circ} \mathrm{C}$, respectively, based on 50-year data of South Khorassan, Iran. A cultivar selection was done according to fruit yields and their quality (Varasteh et al. 2006). Plants grew in a loamy soil with the space among plants of $2 \times 4 \mathrm{~m}$ in rectangular pattern (see the text table below). reduced and it limits photosynthesis (Lawlor and Cornic 2002) and photon flux energy used for photochemistry (Cornic 1994). Chlorophyll (Chl) fluorescence yield can show stress or damage to the photosynthetic apparatus (Glynn et al. 2003). Various reports focus on Chl fluorescence parameters in plants subjected to drought (Petsas and Grammatikopoulos 2009, Khaleghi et al. 2012), freezing (Percival and Fraser 2001), ozone (Meinander et al. 1996), and salinity (Ranjbarfordoei et al. 2006, GarcíaSánchez and Syvertsen 2006, Kalaji et al. 2011). Jain and Dass (1988) and Patil and Waghmare (1982) reported that plant height, number of leaves, and stem diameter of pomegranate plants decreased significantly with increasing soil salinity. They recommended that pomegranate should not grow in soils with electrical conductivity (EC) of saturation paste more than $10 \mathrm{dS} \mathrm{m}^{-1}$. Doring and Ludders (1986, 1987) and Naeini et al. (2006) reported that salinity strongly reduced growth parameters of pomegranates and found the highest accumulation of $\mathrm{Na}^{+}$and $\mathrm{Cl}^{-}$in roots and leaves, respectively. Bhantana and Lazarovitch (2010) listed pomegranate as moderately sensitive. Holland et al. (2009) noted that pomegranates are amenable to irrigation with saline water (EC of 2.5 to $4.0 \mathrm{dS} \mathrm{m}^{-1}$ ) and they produce a normal yield. Levin (2006) reported positive response to irrigation with recycled water in pomegranate orchards in Turkmenistan. Malas and Shishe are commercial Iranian cultivars used for export markets. Both cultivars are late-ripening, medium to large size, with red skin and arils (Varasteh et al. 2006), but different in their shape. Although there are some reports about pomegranate responses to $\mathrm{NaCl}$, no study refers to salinity responses of these cultivars under field conditions. Moreover, Chl fluorescence has not been studied in pomegranates under salt stress. Therefore we studied the physiological mechanisms operating at the whole-plant and cellular levels in these pomegranate cultivars under $\mathrm{NaCl}$ stress. We aimed also to estimate their abilities to exclude $\mathrm{Na}^{+}$or $\mathrm{Cl}^{-}$. Our results could be used in a breeding program designed to enhance salt tolerance in Iranian pomegranates.

As salinity treatments, plants were irrigated by water of different EC: C (control), S1 (EC $4.61 \mathrm{dS} \mathrm{m}^{-1}$ ), and S2 (EC $7.46 \mathrm{dS} \mathrm{m}^{-1}$ ) (Table 1). Irrigation was done according to calibration by data collected from evaporation pan (class A), oven method (Black 1965), pressure plates (Roades 1982), and tensiometer (Santa Barbara, USA) reading [0.03 $\mathrm{MPa}, 30 \mathrm{KPa}$ or field capacity] to avoid water stress in plants. For equal irrigation, the volume of water was calculated using counters connected to each pipe. At the end of experiment, saturated pastes of treated soils were analyzed (Table 2). 


$\begin{array}{ll}\mathrm{EC} & 0.93 \mathrm{dS} \mathrm{m}^{-1} \\ \mathrm{pH} & 7.12 \\ \text { Total N } & 0.08 \% \\ \mathrm{P} & 8 \mathrm{mg} \mathrm{kg}^{-1} \\ \mathrm{~K}^{+} & 210 \mathrm{mg} \mathrm{kg}^{-1} \\ \mathrm{Zn}^{2+} & 0.63 \mathrm{mg} \mathrm{kg}^{-1} \\ \mathrm{Cu}^{2+} & 0.25 \mathrm{mg} \mathrm{kg}^{-1} \\ \mathrm{Mn}^{2+} & 1.96 \mathrm{mg} \mathrm{kg}^{-1} \\ \mathrm{Fe}^{2+} & 2.65 \mathrm{mg} \mathrm{kg}^{-1} \\ \mathrm{Na}^{+} & 4 \mathrm{meq} \mathrm{l} \\ \mathrm{Mg}^{-1} & 3.14 \mathrm{meq} \mathrm{l}^{-1} \\ \mathrm{Ca}^{2+} & 2.6 \mathrm{meq} \mathrm{l}^{-1} \\ \mathrm{Cl}^{-} & 0.5 \mathrm{meq} \mathrm{l} \\ \mathrm{HCO}_{3}^{-1} & 0.3 \mathrm{meq} \mathrm{l}^{-1}\end{array}$

Growth parameters: On each plant, the trunk length (TL) and trunk diameter (TD) were assessed during the growing season. TL was measured via assessment of vertical line related to the soil surface, from the highest to the lowest point of the tree. For TD, the basal part of the mentioned shoot was evaluated by Vernier calliper.

Leaf discs $\left(0.5 \mathrm{~cm}^{2}\right)$ were cut and oven-dried under $100^{\circ} \mathrm{C}$ for $48 \mathrm{~h}$. Then specific leaf mass (SLM) and specific leaf area (SLA) were calculated using method of Hunt (1990):

$\mathrm{SLM}=\frac{\text { Disc dry mass }}{0.5} \quad \mathrm{SLA}=\frac{0.5}{\text { Disc dry mass }}$

Leaf ion leakage (LIL): Large leaf segments were cut out at random, washed 3 times with distilled water in order to remove surface contaminants, and then placed individually in stoppered vials containing $10 \mathrm{ml}$ of distilled water. Consequently, they were incubated at room temperature $\left(25^{\circ} \mathrm{C}\right)$ on a shaker $(100 \times g)$ for $24 \mathrm{~h}$ to measure $\mathrm{EC}$ of the solution $\left(\mathrm{EC}_{1}\right)$. Then the same vials with leaf samples were placed in an autoclave at $120^{\circ} \mathrm{C}$ for $20 \mathrm{~min}$ and the $2^{\text {nd }}$ measurement of conductivity $\left(\mathrm{EC}_{2}\right)$ was done after cooling the solution to room temperature. The ion leakage was calculated as $\frac{\mathrm{EC}_{1}}{\mathrm{EC}_{2}}$ (Lutts et al. 1995).
Relative water content (RWC): Leaf discs $\left(1.5 \mathrm{~cm}^{2}\right)$ were weighed to determine the fresh mass (FM), soaked in distilled water at $25^{\circ} \mathrm{C}$ for $4 \mathrm{~h}$ to determine the turgid mass (TM), then oven-dried at $80^{\circ} \mathrm{C}$ for $24 \mathrm{~h}$ to determine the dry mass (DM). Finally, following equation was used to calculate RWC (Barrs and Weatherley 1962):

$\mathrm{RWC}[\%]=\frac{(\mathrm{FM}-\mathrm{DM})}{(\mathrm{TM}-\mathrm{DM})} \times 100$

Stomatal conductance $\left(\boldsymbol{g}_{\mathrm{s}}\right)$ was determined by leaf porometer (DECAGON DEVICES, INC., Pullman, USA) during the growing season. Measurements were done at $25^{\circ} \mathrm{C}$ at 9:00 to $12: 00 \mathrm{~h}$.

Chl, proline, and total soluble carbohydrates: Chl content was determined by method of Saini et al. (2001) using $80 \%$ acetone or by SPAD 502 meter (MINOLTA, Osaka, Japan). Leaf discs of $0.25 \mathrm{~g}(\mathrm{FM})$ were extracted in $5 \mathrm{ml}$ of acetone $(80 \%)$, then centrifuged for $10 \mathrm{~min}$ in $8,000 \times g$. The supernatant was used to make a final volume of $50 \mathrm{ml}$ of the leaf extract. Extraction of leaf tissue with the buffer continued until decoloration. Absorbance of the extract was read at 645 and $663 \mathrm{~nm}$ with a spectrophotometer (SHIMADZU AA-670, Japan) and $80 \%$ acetone was used as a blank. Finally, total leaf $\mathrm{Chl}$ content was calculated according to the following equation:

Total Chl $=\frac{\left(20.2 \mathrm{~A}_{645}+8.02 \mathrm{~A}_{663}\right) \times \mathrm{V}}{\mathrm{W}} \times 1000$,

where $\mathrm{V}$ is volume $(50 \mathrm{ml}), \mathrm{W}$ is fresh mass of the leaf disc $(0.25 \mathrm{~g}), \mathrm{A}_{645}$ and $\mathrm{A}_{663}$ are absorbances at 645 and $663 \mathrm{~nm}$, respectively.

Proline was determined by the ninhydrin method described by Bates et al. (1973), using L-proline as a standard (0-500 $\mu \mathrm{mol}, \mathrm{MERCK})$. Leaf samples of $0.5 \mathrm{~g}(\mathrm{FM})$ were homogenized in $10 \mathrm{ml}$ of $3 \%(\mathrm{w} / \mathrm{v})$ aqueous sulfosalicylic acid and centrifuged for $30 \mathrm{~min}$ at $14,000 \times \mathrm{g}$.

Table 1. Evaluation of water quality used in the experiment. $\mathrm{EC}=1.05 \mathrm{dS} \mathrm{m}^{-1}$ was used as control (C). $\mathrm{S} 1-\mathrm{EC}$ of $4.61 \mathrm{dS} \mathrm{m}^{-1}$; $\mathrm{S} 2-\mathrm{EC}$ of $7.46 \mathrm{dS} \mathrm{m}^{-1}$.

\begin{tabular}{lllllllll}
\hline Treatment & $\mathrm{EC}$ of $\mathrm{H}_{2} \mathrm{O}\left[\mathrm{dS} \mathrm{m}^{-1}\right]$ & $\mathrm{pH}$ & $\mathrm{Ca}^{2+}\left[\mathrm{meq} 1^{-1}\right]$ & $\mathrm{Mg}^{2+}\left[\mathrm{meq}^{-1}\right]$ & $\mathrm{K}^{+}\left[\mathrm{meq} 1^{-1}\right]$ & $\mathrm{Na}^{+}\left[\mathrm{meq}^{-1}\right]$ & $\mathrm{Cl}^{-}\left[\mathrm{meq}^{-1}\right]$ & $\mathrm{HCO}_{3}^{-}\left[\mathrm{meq}^{-1}\right]$ \\
\hline 1 & $1.05(\mathrm{C})$ & 7.54 & 2.1 & 5.8 & 0.2 & 8.5 & 13.0 & 3.9 \\
2 & $4.61(\mathrm{~S} 1)$ & 7.41 & 7.0 & 18.4 & 0.7 & 23.8 & 14.0 & 2.3 \\
3 & $7.46(\mathrm{~S} 2)$ & 7.26 & 12.7 & 25.0 & 1.1 & 77.3 & 63.0 & 0.9 \\
\hline
\end{tabular}

Table 2. Evaluation of soil saturated paste in each treatment. Treatment 1 was used as control.

\begin{tabular}{llllll}
\hline Treatment & $\mathrm{EC}$ of $\mathrm{H}_{2} \mathrm{O}\left[\mathrm{dS} \mathrm{m}^{-1}\right]$ & $\mathrm{pH}$ & $\mathrm{Na}^{+}\left[\mathrm{meq} \mathrm{l}^{-1}\right]$ & $\mathrm{Cl}^{-}\left[\mathrm{meq} \mathrm{l}^{-1}\right]$ & $\mathrm{K}^{+}\left[\mathrm{meq} \mathrm{l}^{-1}\right]$ \\
\hline 1 & 2.35 & 8.20 & 15.11 & 1.52 & 4.45 \\
2 & 7.13 & 8.05 & 67.73 & 1.75 & 4.45 \\
3 & 9.26 & 8.04 & 86.29 & 2.01 & 4.19 \\
\hline
\end{tabular}


Ninhydrin (2 ml) and glacial acetic acid $(2 \mathrm{ml})$ were added to the supernatant and the mixture was boiled at $100^{\circ} \mathrm{C}$ for $1 \mathrm{~h}$ and then placed in an ice bath to stop the reaction. After extraction with toluene, free proline was quantified at $520 \mathrm{~nm}$ using a spectrophotometer (SHIMADZU AA-670, Japan). Equation used for standard curve preparation was $\mathrm{y}=252.38 \mathrm{x}-8.25\left(R^{2}=0.90\right)$.

The total leaf soluble carbohydrates were determined according to Irigoyen et al. (1992) and glucose (0-100 $\mathrm{mg} \mathrm{1}^{-1}$, from $M E R C K$ ) was used as a standard. Leaf samples of $0.5 \mathrm{~g}(\mathrm{FM})$ were homogenized in $5 \mathrm{ml}$ ethanol $(95 \%)$ and centrifuged at $4,500 \times g$ for $15 \mathrm{~min}$, the supernatant was removed from the sample and the residue was resuspended in $5 \mathrm{ml}$ of $70 \%$ ethanol. Then the supernatant was centrifuged again for final extraction. Both supernatants were combined. Anthrone-sulfuric acid assay was used for determination. An aliquot of $100 \mu \mathrm{l}$ was added to $3 \mathrm{ml}$ of anthrone-sulfuric acid solution and the mixture was shaken, heated in a boiling water bath for $10 \mathrm{~min}$ and cooled at $4^{\circ} \mathrm{C}$. The absorption at $625 \mathrm{~nm}$ was determined by spectrophotometer (SHIMADZU AA-670, Japan). Equation used for standard curve preparation was $\mathrm{y}=545.04 \mathrm{x}-29.973\left(R^{2}=0.94\right)$.

Chl fluorescence was measured on the top, attached, and dark-adapted leaf of each plant using a MINI PAM fluorometer ( $W A L Z$, Effeltrich, Germany) according to the protocol of Genty et al. (1989). Leaves were kept for $30 \mathrm{~min}$ in the dark-adapted state using light-exclusion clips. At this state, all reaction centers and electron carriers of PSII are reoxidized, which is necessary for the rapid induction of fluorescence. Under such condition, nonphotochemical quenching $\left(\mathrm{q}_{\mathrm{N}}\right)$ is relaxed to its minimum value (Roháček 2002, Zhang and Xu 2003). Low-intensity modulated light $\left(<0.1 \mu \mathrm{mol} \mathrm{m}{ }^{-2} \mathrm{~s}^{-1}\right)$ was used to measure

\section{Results}

Water and soil analysis: The final EC of soil-saturated paste (SSP) increased to 2.35, 7.13, and $9.26 \mathrm{dS} \mathrm{m}^{-1}$ in C, $\mathrm{S} 1$, and S2 treatments, respectively. The $\mathrm{Na}^{+}$and $\mathrm{Cl}^{-}$ concentrations in SSP rose with increasing content of these ions in the irrigation water (Table 1 ). Although $\mathrm{K}^{+}$concentration of irrigation water increased with salinity increment, the lowest $\mathrm{K}^{+}$in SSP was found in $\mathrm{EC}=7.46$ $\mathrm{dS} \mathrm{m} \mathrm{m}^{-1}$ (Table 2).

Growth parameters, LIL, and RWC: The highest TL was found in $\mathrm{C}$ treatment for both cultivars. The significant difference in TL was observed among S2 and S1 treatments. Although TL was reduced in S1, it increased at S2 (Table 3). TD of both cultivars affected significantly salinity, compared with C. In Malas, TD increased significantly with salinity, but it decreased in Shishe cultivar. SLM was unaffected by different treatments, however, SLA showed significant change. The highest SLA was at $\mathrm{S} 1$ in both cultivars and it declined significantly with the minimum fluorescence $\left(\mathrm{F}_{0}\right)$. The maximum fluorescence $\left(\mathrm{F}_{\mathrm{m}}\right)$ was obtained by 0.3 -s pulses of saturating light of $20,000 \mathrm{~Hz}$. The maximum photochemical efficiency of PSII, $\mathrm{F}_{\mathrm{v}} / \mathrm{F}_{\mathrm{m}}$, was calculated according to Kitajima and Butler (1975). Concurrently, both the minimum Chl fluorescence in the light-adapted state $\left(F_{s}\right)$ and the maximum $\mathrm{Chl}$ fluorescence in the light-adapted state $\left(\mathrm{F}_{\mathrm{m}}{ }^{\prime}\right)$ were measured. The effective quantum yield of photochemical energy conversion in PSII was calculated according to Genty et al. (1989) as: $\Phi_{\mathrm{PSII}}=\frac{\left(\mathrm{F}_{\mathrm{m}}{ }^{\prime}-\mathrm{F}_{\mathrm{s}}\right)}{\mathrm{F}_{\mathrm{m}}{ }^{\prime}}$

Nutrient analysis and current shoot growth: Chemical analysis was carried out with oven-dried samples of leaves and current shoot tissues, which were ground separately and ashed at $550^{\circ} \mathrm{C}$ for $90 \mathrm{~min}$ in a porcelain crucible. $\mathrm{Na}^{+}$, $\mathrm{K}^{+}$, and $\mathrm{Cl}^{-}$were determined in these samples. The ash was resuspended in hot $2 \mathrm{M} \mathrm{HCl}$, filtered, made up to $50 \mathrm{ml}$ with distilled water, and then used for $\mathrm{Na}^{+}$and $\mathrm{K}^{+}$analysis with a flame photometer (CORNING 405, Cambridge, UK). Concentration of $\mathrm{Cl}^{-}$was assessed by the titration method (Chapman and Pratt 1982).

Statistical analysis: The experiment was set up in a completely randomized block design, consisting of three blocks, each block consisted of three saline treatments and two cultivars (each cultivar containing 30 trees), where salinity was used as a main factor. We assumed that all the measured data came from normal (Gaussian) data distribution even if it was not always true, especially, in the case of fluorescence measurements (Lazár et al. 1998, 2006). Statistical analysis of data was carried out using analysis of variance (ANOVA) procedure on GENSTAT. The averages were compared with Duncan's multiple range test at $5 \%$ level.

further salinity increment. Moreover, the lowest value was observed in Shishe (Table 3). LIL of Malas remained unaffected at different levels of salinity, however, increasing salt stress enhanced significantly LIL in Shishe. RWC of both cultivars declined by salinity increment, the lowest values were found at S1. Moreover, the lowest RWC were shown in Shishe under both S1 and S2 treatments (Table 3 ).

$g_{\mathrm{s}}$, Chl content, proline, and total soluble carbohydrates: Malas showed significant reduction in $g_{\mathrm{s}}$ under salinity, compared with C. In Shishe, $g_{\mathrm{s}}$ increased significantly from $\mathrm{C}$ to $\mathrm{S} 1$ treatments, and then declined in $\mathrm{S} 2$ (Table 4).

Total Chl content in both cultivars lowered significantly with increasing salinity; the lowest amount was observed in S1. In both cultivars, higher Chl content was found in S2 compared with S1 treatment (Table 4). Proline accumulation in Malas declined significantly from $\mathrm{C}$ to $\mathrm{S} 1$ 
Table 3. Effects of salinized waters on trunk length (TL) and diameter (TD), specific leaf mass (SLM), specific leaf area (SLA), leaf ion leakage (LIL), and relative water content (RWC). $\mathrm{EC}=1.05 \mathrm{~d} \mathrm{Sm}^{-1}$ was used as control. Mean values in each column followed by the same letter are not significantly different $(P<0.05)$ by the Duncan's multiple range test.

\begin{tabular}{lccllll}
\hline EC of $\mathrm{H}_{2} \mathrm{O}\left[\mathrm{dS} \mathrm{m}^{-1}\right]$ & $\mathrm{TL}[\mathrm{cm}]$ & $\mathrm{TD}[\mathrm{mm}]$ & $\mathrm{SLM}\left[\mathrm{g} \mathrm{cm}^{-2}\right]$ & $\mathrm{SLA}\left[\mathrm{cm}^{2} \mathrm{~g}^{-1}\right]$ & LIL [\%] & RWC [\%] \\
\hline Malas-e-Saveh & & & & & & \\
$1.05(\mathrm{C})$ & $78.10^{\mathrm{b}}$ & $10.12^{\mathrm{c}}$ & $0.011^{\mathrm{a}}$ & $95.01^{\mathrm{c}}$ & $0.153^{\mathrm{bc}}$ & $71.17^{\mathrm{b}}$ \\
$4.61(\mathrm{~S} 1)$ & $63.00^{\mathrm{e}}$ & $10.40^{\mathrm{b}}$ & $0.010^{\mathrm{a}}$ & $104.27^{\mathrm{b}}$ & $0.193^{\mathrm{ab}}$ & $69.00^{\mathrm{d}}$ \\
$7.46(\mathrm{~S} 2)$ & $70.30^{\mathrm{d}}$ & $10.65^{\mathrm{a}}$ & $0.010^{\mathrm{a}}$ & $98.97^{\mathrm{c}}$ & $0.187^{\mathrm{abc}}$ & $70.67^{\mathrm{c}}$ \\
Shishe-Kab & & & & & & \\
$1.05(\mathrm{C})$ & $87.60^{\mathrm{a}}$ & $10.38^{\mathrm{b}}$ & $0.011^{\mathrm{a}}$ & $97.69^{\mathrm{d}}$ & $0.130^{\mathrm{c}}$ & $71.83^{\mathrm{a}}$ \\
$4.61(\mathrm{~S} 1)$ & $58.60^{\mathrm{f}}$ & $8.97^{\mathrm{e}}$ & $0.010^{\mathrm{a}}$ & $113.57^{\mathrm{a}}$ & $0.163^{\mathrm{bc}}$ & $66.17^{\mathrm{f}}$ \\
$7.46(\mathrm{~S} 2)$ & $73.00^{\mathrm{c}}$ & $9.43^{\mathrm{d}}$ & $0.010^{\mathrm{a}}$ & $84.30^{\mathrm{f}}$ & $0.243^{\mathrm{a}}$ & $67.67^{\mathrm{e}}$ \\
\hline
\end{tabular}

Table 4. Effects of salinized water on leaf total chlorophyll $(\mathrm{Chl})$, stomatal conductance $\left(g_{\mathrm{s}}\right)$, proline, and total carbohydrate contents. $\mathrm{EC}=1.05 \mathrm{dS} \mathrm{m}^{-1}$ was used as control. Mean values in each column followed by the same letter are not significantly different $(P<0.05)$ by the Duncan's multiple range test.

\begin{tabular}{|c|c|c|c|c|}
\hline $\begin{array}{l}\mathrm{EC} \text { of } \mathrm{H}_{2} \mathrm{O} \\
{\left[\mathrm{dS} \mathrm{m}^{-1}\right]}\end{array}$ & $\begin{array}{l}\text { Chl } \\
{\left[\mathrm{mg} \mathrm{g}^{-1}(\mathrm{FM})\right]}\end{array}$ & $\begin{array}{l}g_{\mathrm{s}} \\
{\left[\mathrm{mmol} \mathrm{m}{ }^{-2} \mathrm{~s}^{-1}\right]}\end{array}$ & $\begin{array}{l}\text { Proline } \\
{\left[\mu \mathrm{mol} \mathrm{g}{ }^{-1}(\mathrm{FM})\right]}\end{array}$ & $\begin{array}{l}\text { Carbohydrates } \\
{\left[\mathrm{mg} \mathrm{g}^{-1}(\mathrm{FM})\right]}\end{array}$ \\
\hline \multicolumn{5}{|c|}{ Malas-e-Saveh } \\
\hline $1.05(\mathrm{C})$ & $1.896^{\mathrm{b}}$ & $151.20^{\mathrm{a}}$ & $605.00^{c}$ & $306.30^{c}$ \\
\hline 4.61 (S1) & $1.535^{\mathrm{d}}$ & $145.70^{c}$ & $577.90^{\mathrm{d}}$ & $315.00^{\mathrm{a}}$ \\
\hline $7.46(\mathrm{~S} 2)$ & $1.612^{\mathrm{c}}$ & $147.90^{\mathrm{b}}$ & $636.00^{\mathrm{a}}$ & $292.30^{\mathrm{e}}$ \\
\hline \multicolumn{5}{|l|}{ Shishe-Kab } \\
\hline $1.05(\mathrm{C})$ & $1.991^{\mathrm{a}}$ & $133.20^{\mathrm{e}}$ & $558.80^{f}$ & $315.00^{\mathrm{a}}$ \\
\hline $4.61(\mathrm{~S} 1)$ & $1.301^{\mathrm{e}}$ & $133.60^{\mathrm{d}}$ & $573.90^{\mathrm{e}}$ & $309.70^{\mathrm{b}}$ \\
\hline 7.46 (S2) & $1.602^{\mathrm{c}}$ & $114.10^{f}$ & $605.40^{\mathrm{b}}$ & $294.00^{\mathrm{d}}$ \\
\hline
\end{tabular}

Table 5. Effects of salinized water on current shoot potassium, sodium, and chloride concentrations. EC $=1.05 \mathrm{dS} \mathrm{m}^{-1}$ was used as control. Mean values in each column followed by the same letter are not significantly different $(P<0.05)$ by the Duncan's multiple range test.

\begin{tabular}{lllll}
\hline $\begin{array}{l}\mathrm{EC} \mathrm{of} \mathrm{H}_{2} \mathrm{O} \\
{\left[\mathrm{dS} \mathrm{m}{ }^{-1}\right]}\end{array}$ & $\begin{array}{l}\mathrm{Na}^{+} \\
{\left[\mathrm{mg} \mathrm{g}^{-1}(\mathrm{DM})\right]}\end{array}$ & $\begin{array}{l}\mathrm{Cl}^{-} \\
{\left[\mathrm{mg} \mathrm{g}^{-1}(\mathrm{DM})\right]}\end{array}$ & $\begin{array}{l}\mathrm{K}^{+} \\
{\left[\mathrm{mg} \mathrm{g}^{-1}(\mathrm{DM})\right]}\end{array}$ & $\begin{array}{l}\mathrm{K}^{+} / \mathrm{Na}^{+} \\
\text {ratio }\end{array}$ \\
\hline $\begin{array}{l}\text { Malas-e-Saveh } \\
1.05(\mathrm{C})\end{array}$ & $6.81^{\mathrm{d}}$ & $0.52^{\mathrm{a}}$ & $16.40^{\mathrm{a}}$ & $2.42^{\mathrm{a}}$ \\
$4.61(\mathrm{~S} 1)$ & $8.66 \mathrm{~b}^{\mathrm{c}}$ & $0.51^{\mathrm{a}}$ & $14.35^{\mathrm{a}}$ & $1.73^{\mathrm{c}}$ \\
$7.46(\mathrm{~S} 2)$ & $11.12^{\mathrm{b}}$ & $0.44^{\mathrm{a}}$ & $13.62^{\mathrm{a}}$ & $1.26^{\mathrm{e}}$ \\
Shishe-Kab & & & & \\
$1.05(\mathrm{C})$ & $6.86^{\mathrm{d}}$ & $0.41^{\mathrm{a}}$ & $16.00^{\mathrm{a}}$ & $2.33^{\mathrm{b}}$ \\
$4.61(\mathrm{~S} 1)$ & $12.00^{\mathrm{a}}$ & $0.55^{\mathrm{a}}$ & $13.67^{\mathrm{a}}$ & $1.14^{\mathrm{f}}$ \\
$7.46(\mathrm{~S} 2)$ & $11.12^{\mathrm{b}}$ & $0.65^{\mathrm{a}}$ & $14.03^{\mathrm{a}}$ & $1.42^{\mathrm{d}}$ \\
\hline
\end{tabular}

and then increased in S2. In Shishe, proline content increased with rising salinity. The highest proline accumulation was obtained at S2 in Malas. Accumulation of total carbohydrates showed an opposite trend compared to proline. In Malas, the highest and lowest carbohydrate contents were observed at S1 and S2, respectively. In Shishe, the carbohydrate content declined with increasing salinity (Table 4).

Chl fluorescence parameters were strongly influenced by salinity stress. In both cultivars, $\mathrm{F}_{0}$ showed the lowest value under $C$. It increased significantly with salinity increment (data not shown), while $\mathrm{F}_{\mathrm{m}}$ declined continuously compared with $\mathrm{C}$. The lowest value was observed in Shishe under S2 (data not shown). With increasing salinity, the ratio of $\mathrm{F}_{0} / \mathrm{F}_{\mathrm{m}}$ significantly increased in both cultivars, compared with $\mathrm{C}$, and the highest value was observed in Shishe under S2. No significant difference was found between S1 and S2 treatments in Malas (Fig. 1). With increasing salinity, the $F_{v} / F_{m}$ was significantly 
reduced in both cultivars (Fig. 2) and the lowest value was found in Shishe under $S 2$. The ratio of $F_{v} / F_{0}$ decreased significantly as salinity level increased and the lowest ratio was observed in Shishe under S2. In Malas, no significant difference between S1 and S2 treatments (Fig. 3).

The $\Phi_{\text {PSII }}$ (Fig. 4) showed opposite trend and it declined significantly in both cultivars compared with $\mathrm{C}$. The lowest value was observed in Shishe under the highest salinity.

Nutrient analysis of current shoot and leaf tissues: As salinity level increased from $\mathrm{C}$ to $\mathrm{S} 2, \mathrm{Na}^{+}$accumulated significantly in current shoots of Malas (Table 5). In Shishe, $\mathrm{Na}^{+}$content increased from $\mathrm{C}$ to $\mathrm{S} 1$, while it declined in $\mathrm{S} 2 . \mathrm{Cl}^{-}$and $\mathrm{K}^{+}$concentrations remained unaffected by cultivar and salinity levels, although $\mathrm{K}^{+}$ accumulated more than $\mathrm{Na}^{+}$(Table 5). In both cultivars,

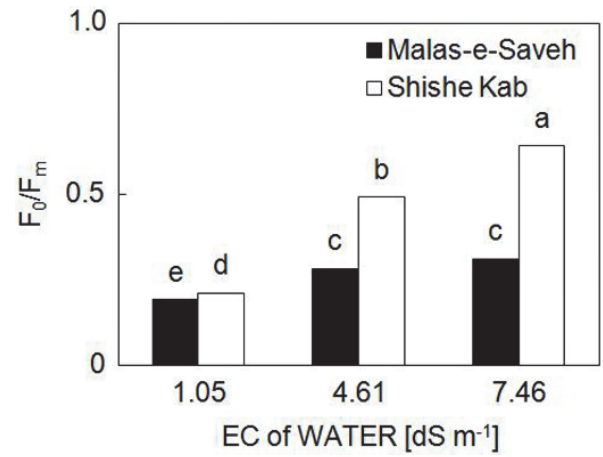

Fig. 1. Evaluation of $\mathrm{F}_{0} / \mathrm{F}_{\mathrm{m}}$ under salinity stress. Means of 30 replications. Bars with the same letters are not significantly different according to Duncan's multiple range test at 5\% level. $\mathrm{F}_{0}$ - the minimal fluorescence in the dark-adapted state, $\mathrm{F}_{\mathrm{m}}$ - the maximal fluorescence in the dark-adapted state.

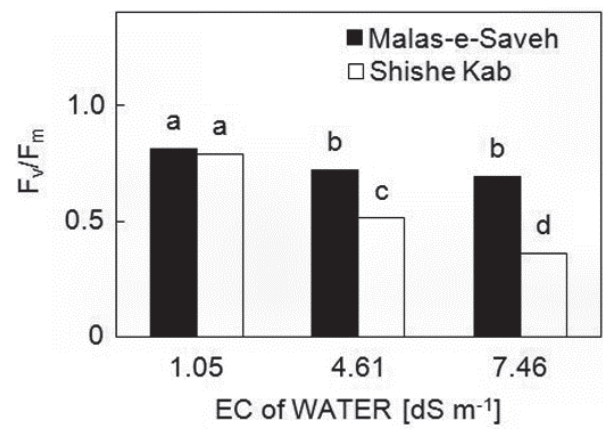

Fig. 2. Evaluation of $F_{v} / F_{m}$ under salinity stress. Means of 30 replications. Bars with the same letters are not significantly different according to Duncan's multiple range test at 5\% level. $\mathrm{F}_{\mathrm{v}}$ - variable fluorescence, $\mathrm{F}_{\mathrm{m}}$ - the maximal fluorescence in the dark-adapted state, $F_{v} / F_{m}-$ the maximum quantum yield of PSII or maximum PSII photochemical efficiency. the $\mathrm{K}^{+} / \mathrm{Na}^{+}$ratio decreased significantly with increasing salinity, although the ratio declined from $\mathrm{C}$ to $\mathrm{S} 1$ and then increased at $\mathrm{S} 2$ in Shishe (Table 5). With increasing salinity, $\mathrm{Na}^{+}$concentration rose in Malas, however, it showed increment from 1.05 to 4.61 and then reduced from 4.61 to $7.46 \mathrm{dS} \mathrm{m}^{-1}$ in Shishe (Table 6). Significant difference between cultivars appeared in leaf $\mathrm{Cl}^{-}$accumulation. With increasing salinity, $\mathrm{Cl}^{-}$accumulation in leaves increased significantly in Malas, while it was significantly reduced in leaves of Shishe (Table 6). Accumulation of $\mathrm{K}^{+}$ increased from $\mathrm{C}$ to $\mathrm{S} 1$ and then declined in $\mathrm{S} 2$ in leaves of Malas, it increased with salinity increment in Shishe. $\mathrm{K}^{+}$ accumulated more in leaves than $\mathrm{Na}^{+}$. The $\mathrm{K}^{+} / \mathrm{Na}^{+}$ratio was significantly smaller in leaves of Malas under higher salinity, while it increased from $\mathrm{C}$ to $\mathrm{S} 1$ and then declined at S2 in Shishe (Table 6).

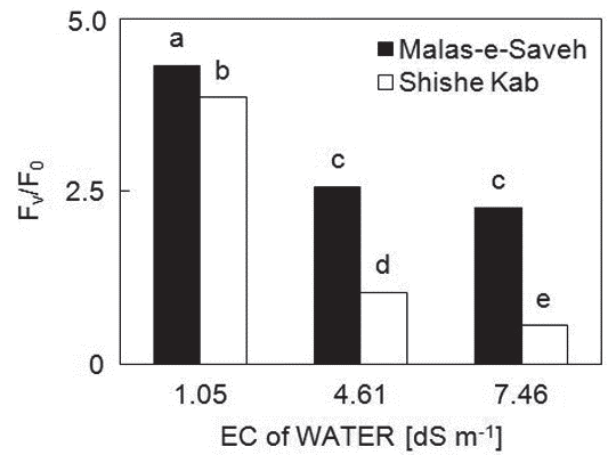

Fig. 3. Evaluation of $F_{v} / F_{0}$ under salinity stress. Means of 30 replications. Bars with the same letters are not significantly different according to Duncan's multiple range test at 5\% level. $\mathrm{F}_{\mathrm{v}}$ - variable fluorescence, $\mathrm{F}_{0}$ - the minimal fluorescence in the dark-adapted state.

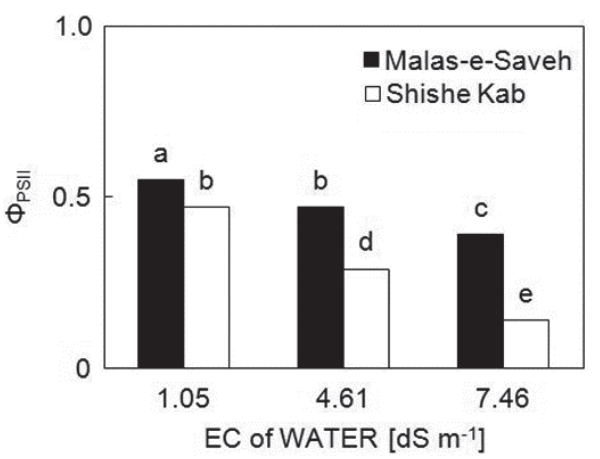

Fig. 4. Evaluation of $\Phi_{\text {PSII }}$ under salinity stress. Means of 30 replications. Bars with the same letters are not significantly different according to Duncan's multiple range test at 5\% level.

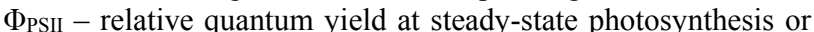
effective quantum yield of photochemical energy conversion in PSII. 
Table 6. Effects of salinized water on leaf potassium, sodium, and chloride concentrations. $\mathrm{EC}=1.05 \mathrm{dS} \mathrm{m}^{-1}$ was used as control. Mean values in each column followed by the same letter are not significantly different $(P<0.05)$ by the Duncan's multiple range test.

\begin{tabular}{lllll}
\hline $\begin{array}{l}\text { EC of } \mathrm{H}_{2} \mathrm{O} \\
\left.[\mathrm{dS} \mathrm{m})^{-1}\right]\end{array}$ & $\begin{array}{l}\mathrm{Na}^{+} \\
{\left[\mathrm{mg} \mathrm{g}^{-1}(\mathrm{DM})\right]}\end{array}$ & $\begin{array}{l}\mathrm{Cl}^{-} \\
{\left[\mathrm{mg} \mathrm{g}^{-1}(\mathrm{DM})\right]}\end{array}$ & $\begin{array}{l}\mathrm{K}^{+} \\
{\left[\mathrm{mg} \mathrm{g}^{-1}(\mathrm{DM})\right]}\end{array}$ & $\begin{array}{l}\mathrm{K}^{+} / \mathrm{Na}^{+} \\
\text {ratio }\end{array}$ \\
\hline $\begin{array}{l}\text { Malas-e-Saveh } \\
1.05(\mathrm{C})\end{array}$ & $4.00^{\mathrm{e}}$ & $4.28^{\mathrm{f}}$ & $10.61^{\mathrm{f}}$ & $2.68^{\mathrm{c}}$ \\
$4.61(\mathrm{~S} 1)$ & $6.36^{\mathrm{b}}$ & $6.82^{\mathrm{c}}$ & $16.00^{\mathrm{c}}$ & $2.50^{\mathrm{d}}$ \\
$7.46(\mathrm{~S} 2)$ & $8.01^{\mathrm{a}}$ & $8.38^{\mathrm{a}}$ & $11.88^{\mathrm{e}}$ & $2.13^{\mathrm{e}}$ \\
Shishe-Kab & & & & \\
$1.05(\mathrm{C})$ & $3.63^{\mathrm{f}}$ & $7.53^{\mathrm{b}}$ & $15.94^{\mathrm{d}}$ & $4.40^{\mathrm{a}}$ \\
$4.61(\mathrm{~S} 1)$ & $6.30^{\mathrm{c}}$ & $6.72^{\mathrm{d}}$ & $16.26^{\mathrm{b}}$ & $2.70^{\mathrm{c}}$ \\
$7.46(\mathrm{~S} 2)$ & $4.18^{\mathrm{d}}$ & $5.02^{\mathrm{e}}$ & $16.51^{\mathrm{a}}$ & $3.96^{\mathrm{b}}$ \\
\hline
\end{tabular}

Correlations: Regression analysis showed a linear correlation $\left(R^{2}=0.77\right)$ between ion leakage and accumulation of $\mathrm{Na}^{+}$in leaves of Malas (data not shown). Ion leakage correlated linearly with $\mathrm{K}^{+}$content in leaves of Malas $\left(R^{2}=0.54\right)$ and Shishe $\left(R^{2}=0.91\right)$. A negative

\section{Discussion}

We found that pomegranates could tolerate ECs lesser than $10 \mathrm{dS} \mathrm{m}^{-1}$ in SSP. It was in agreement with findings of Patil and Waghmare (1982).

The TL affected by salinity stress (Table 3 ) was reported in pomegranate (Jain and Dass 1988, Patil and Waghmare 1982) and also in olive (Naeini et al. 2006, Chen et al. 2007, Goreta et al. 2007, Ben Ahmed et al. 2008). Reduction of TD in Shishe might result from osmotic effects of $\mathrm{NaCl}$ on this cultivar (Table 2). Munns and Tester (2008) suggested that moderate salinity inhibits lateral shoot development that becomes apparent over weeks and it is a response to the osmotic effect of $\mathrm{NaCl}$. The highest SLA in both cultivars was found at $\mathrm{EC}=4.61$ $\mathrm{dS} \mathrm{m}^{-1}$ (Table 3 ). There was a significant difference among treatments for SLA in Shishe (Table 3), similar with findings of Sergio et al. (2012) on chicory, which may result from osmotic effects of salinity on leaf growth of this cultivar. The leaf growth rate decreases when soil salinity increases, primarily due to the osmotic effect of the salt accumulation around the roots (Munns and Tester 2008). This reduction is independent of carbohydrate supply (Munns et al. 2000), water status (Munns et al. 2000, Fricke and Peters 2002), nutrient deficiency (Hu et al. 2005, Hu et al. 2007), and ion toxicity (Munns and Tester 2008). Unaffected LIL of Malas might result from high selectivity for $\mathrm{K}^{+}$absorption by root and replacement of $\mathrm{K}^{+}$by $\mathrm{Na}^{+}$in cell membrane structure. On the other hand, with increasing salinity, LIL significantly increased in Shishe (Table 3). It agreed with results in strawberry (Kaya et al. 2002a, Khayyat et al. 2009a), olive (Goreta et al. 2007, Perica et al. 2008), and Echinacea (Sabra et al. 2012). In some species, membrane permeability changed before the growth reduction or before the appearance of severe chlorosis (Lutts et al. 1996, Mansour and Salama correlation was observed between RWC and leaf $\mathrm{K}^{+}$ content in Malas $\left(R^{2}=1\right)$ and Shishe $\left(R^{2}=0.57\right)$. Moreover, proline accumulation in leaves correlated negatively with carbohydrate content in leaves of Malas $\left(R^{2}=0.99\right)$ and Shishe $\left(R^{2}=0.99\right)$ (data not shown).

2004). RWC decreased first in both cultivars with increasing salinity (S1) and then increased at S2. Both cultivars seemed to improve their water status under salinity (Table 3 ). It was in agreement with findings in pistachio (Behboudian et al. 1986, Hokmabadi et al. 2005), but it was contradictory to results from olive (Goreta et al. 2007) and rice (Khan and Panda 2008). Some researchers (Torrecillas et al. 1995, Hernandez et al. 2000) regard osmotic effects as the way how salt stress affects plant water status. Plants may adjust their osmotic status by accumulation of $\mathrm{Na}^{+}$and $\mathrm{Cl}^{-}$in tissues; however, it may endanger cells and inactivate both photosynthetic and respiratory electron transport (Munns and Tester 2008) Munns and Tester (2008) suggested that salts may build up in the apoplast and dehydrate the cell, which could influence RWC.

Reduction of total Chl contents in both cultivars (Table 4) agreed with results from strawberry (Kaya et al. 2002b, Khayyat et al. 2009b) and cucumber (Tiwari et al. 2010). Although salinity (up to S1) influenced the cultivars via nonstomatal way, Chl increased at S2 (Zaman et al. 2002). Salts might build up in the chloroplast and exert a direct toxic effect on photosynthetic processes (Munns and Tester 2008). Sivstev et al. (1973) reported that salinity could increase chlorophyllase activity or it may influence absorption of some ions, such as $\mathrm{Mg}^{2+}$ and $\mathrm{Fe}^{2+}$, which are involved in Chl formation (Munns 2002). Grattan and Grieve (1999) reported that reduction of Chl led to the reduction of photosynthetic capacity. The $g_{\mathrm{s}}$ of Malas was reduced by $\mathrm{S} 1$, while it increased at $\mathrm{S} 2$. On the other, $g_{\mathrm{s}}$ decreased with salinity increment in Shishe (Table 4), which was in agreement with raspberry (Neocleous and Vasilakakis 2007) and Echinacea (Sabra et al. 2012). A reduction of stomata aperture is the most dramatic and 
readily measurable parameter of the plant response to salinity. It is undoubtedly induced by the osmotic effect of salinity owing to disturbed water relations and finally local synthesis of abscisic acid (ABA) (Fricke et al. 2004). Regulation of $g_{\mathrm{s}}$ is vital for plants under stress conditions, it prevents from desiccation and improves $\mathrm{CO}_{2}$ acquisition (Dodd 2003, Medici et al. 2007). Under salinity, leaf turgor and atmospheric vapor pressure are reduced and chemical signals, such as ABA (Kempa et al. 2008, Melcher et al. 2009), are generated along roots (Chaves et al. 2009). Thus, mesophyll conductance is suppressed (Flexas et al. 2004, Chaves et al. 2009), finally photosynthetic processes might be disrupted and it can affect negatively carbohydrate production. With salinity increment, proline accumulation increased in both cultivars, with higher accumulation in Malas (Table 4). This was in agreement with pistachio (Hokmabadi et al. 2005) and cucumber (Tiwari et al. 2010). The turgor pressure is controlled by solute regulation within the guard cell protoplast and the RWC of epidermal tissues. Accumulation of inorganic and organic solutes increased the osmotic activity; consequently it reduced water potential and an influx of water from the surrounding cells (Munns and Tester 2008). With salinity increment, accumulation of total carbohydrates was reduced significantly in both cultivars (Table 4), which was in agreement with results of Kaya et al. (2002b) for strawberry and of Tiwari et al. (2010) for cucumber. Ashraf and Harris (2013) showed that abiotic stress, such as salinity, disrupts carbohydrate production. Salts may build up in the cytoplasm and inhibit enzymes involved in carbohydrate metabolism (Munns and Tester 2008). Reduction of carbohydrate production may be related to (1) the proline accumulation and (2) accumulation and/or disruption of photosynthetic processes involved in carbohydrate production. If $\mathrm{Na}^{+}$and $\mathrm{Cl}^{-}$are sequestered in the vacuole, compatible organic solutes, such as commonly sucrose, proline, and glycinebetaine, must accumulate in the cytosol and in organelles to balance the osmotic pressure of the ions in the vacuole (Flowers et al. 1977, Jones et al. 1977, Hasegawa et al. 2000, Munns 2005). They function as osmolytes and osmoprotectants, stabilizing the tertiary structure of proteins, and serve as an organic nitrogen source (Rhodes et al. 2002, Sairam and Tyagi 2004).

Chl fluorescence parameters were strongly influenced by salinity stress. In our experiment, $\mathrm{F}_{0}$ significantly increased with salinity increment, which was in agreement with Ranjbarfordoei et al. (2006) in sweet almond. Rising $\mathrm{F}_{0}$ occurs when plants are exposed to extreme environmental stress, which leads to the structural alteration in PSII (Krause and Weis 1984). $F_{m}$ declined continuously with increasing salinity, which was in agreement with Ranjbarfordoei et al. (2006). The increment of $\mathrm{F}_{0}$ and concomitant reduction of $F_{m}$ indicated the impairment of light-harvesting complex in PSII, which finally reduced $F_{v}$. Reduction of $F_{v}$ results in decreasing PSII quantum yield (Fernandez et al. 1997). With rising salinity, $\mathrm{F}_{0} / \mathrm{F}_{\mathrm{m}}$ significantly increased in both cultivars (Fig. 1), similarly to findings of Ranjbarfordoei et al. (2006). The ratio of $\mathrm{F}_{0} / \mathrm{F}_{\mathrm{m}}$ increases significantly in stressed and damaged plants (Bilger et al. 1987, Ranjbarfordoei et al. 2006), because of excitation energy lost during its transfer from pigment bed to the reaction centers and also due to increasing energy loss through nonphotochemical quenching processes (Yordanov et al. 1997, Roháček 2002). The $F_{v} / F_{m}$ declined significantly in both cultivars with increasing stress (Fig. 2), which was in agreement with Ranjbarfordoei et al. (2006). Björkman and Demmig (1987) reported that $F_{v} / F_{m}$ ratio is almost constant for many plant species under optimal conditions and it ranges between 0.80 and 0.86 . Thus, our control plants were not under stress conditions. Bongi and Loreto (1989) reported that salt stress significantly reduced $F_{v} / F_{m}$ of olive. There was a positive correlation between photosynthetic inhibition and reduction of $F_{v} / F_{m}$ (Bongi and Loreto 1989). The significant reduction of the $F_{v} / F_{0}$ ratio under increasing salinity reflects the effect of salt stress on efficiency of the photochemical process and electron transport chain in PSII (Yordanov et al. 1997, Ranjbarfordoei et al. 2006). The significant increment of $F_{s}$ of both cultivars (data not shown) was in agreement with Ranjbarfordoei et al. (2006). On the other hand, reduction of the $F_{m}$ ' and the $\Phi_{\text {PSII }}$ was in agreement with Jimenez et al. (1997), and Ranjbarfordoei et al. (2006). The $\Phi_{\mathrm{PSII}}$ indicates the photochemical capacity of PSII under light conditions. Moreover, this variable shows the actual fraction of reaction centers that are open in PSII (Krause et al. 1982). Juneau et al. (2005) found out $\Phi_{\text {PSII }}$ proportional to the photon energy that is captured by opened reaction centers in PSII. Genty et al. (1989) reported $\Phi_{\text {PSII }}$ as insensitive to some environmental factors. However, $\Phi_{\text {PSII }}$ seemed to be the sensitive indicator of salt stress in our experiment and it was supported also by Ranjbarfordoei et al. (2006). Singh and Dubey (1995) stated that salt stress inhibits PSII activity. Roháček (2002) suggested that $\Phi_{\text {PSII }}$ is related to the actual fraction of photochemically active reaction centers of PSII in light conditions. Thus, fluorescence obtained in the light-adapted state $\left(F_{s}\right.$ and $F^{\prime}$ ) is sensitive to alteration in electron transport between PSII and PSI and to biochemical reactions related to photosynthesis (Lazár 1999). In this work, the entire PSII-PSI electron transport was negatively affected in both cultivars, even more in Shishe.

Elevated $\mathrm{Na}^{+}$concentration in current shoots of both cultivars compared to leaves might result from ion selectivity in root cell membrane and inhibition of its accumulation in leaf tissues or it is related to salt exclusion from leaves. Leaf $\mathrm{Cl}^{-}$accumulation showed significant difference. The transport of $\mathrm{Cl}^{-}$ion occurs mainly in the transpiration stream (Wahome 2003). As $g_{\mathrm{s}}$ of Malas was higher than that of another cultivar, the $\mathrm{Cl}^{-}$concentration increased within the leaf. Although plants generally manage the $\mathrm{Na}^{+}$transport better than $\mathrm{Cl}^{-}$(Munns and Tester 2008), leaf $\mathrm{Cl}^{-}$concentration was similar to $\mathrm{Na}^{+}$in Malas and higher than that of $\mathrm{Na}^{+}$in Shishe. Regarding to 
Tables 5 and 6 , more $\mathrm{Na}^{+}$accumulated in current shoots than in leaves similarly to findings of Neocleous and Vasilakakis (2007) in raspberry, Goreta et al. (2007) in olive, Khan and Panda (2008) in rice and Sabra et al. (2012) in Echinaceae. On the other hand, chloride accumulation increased in leaves, compared to current shoots similarly to findings of Neocleous and Vasilakakis (2007) in raspberry and Sabra et al. (2012) in Echinaceae. Some reports indicated that these salts are toxic to cytoplasm at higher concentrations (Bohnert and Jensen 1996, Nuccio et al. 1999). $\mathrm{Cl}^{-}$are absorbed at higher rates than $\mathrm{Na}^{+}$(Marschner 1995), thus $\mathrm{Cl}^{-}$ions accumulate more than $\mathrm{Na}^{+}$in leaf tissues (Greenway and Munns 1980). This was proved in citrus (Bar et al. 1998, Prior et al. 2007), raspberry (Neocleous and Vasilakakis 2007), soybean, avocado, and grapevine (Munns and Tester 2008).

We concluded that Malas was less affected than Shishe by osmotic effects of $\mathrm{NaCl}$, as proved by growth and RWC reduction and stomata closure. However, Shishe managed $\mathrm{Na}^{+}$and $\mathrm{Cl}^{-}$transport into the leaves better than Malas. Thus, based on ion uptake, it seemed that Shishe might be more tolerant to salinity stress.

Open Access This article is distributed under the terms of the Creative Commons Attribution License which permits any use, distribution, and reproduction in any medium, provided the original author(s) and the source are credited.

\section{References}

Apse, M.P., Blumwald, E.: $\mathrm{Na}^{+}$transport in plants. - FEBS Lett. 581: 2247-2254, 2007.

Ashraf, M.: Organic substances responsible for salt tolerance in Eruca sativa. - Biol. Plantarum 36: 255-259, 1994.

Ashraf, M., Harris, P.J.C.: Photosynthesis under stressful environments: An overview. - Photosynthetica 51: 163-190, 2013.

Ashraf, M., Harris, P.J.C.: Potential biochemical indicators of salinity tolerance in plants. - Plant Sci. 166: 3-16, 2004.

Ashraf, M., Foolad, M.R.: Roles of glycine betaine and proline in improving plant abiotic stress resistance. - Environ. Exp. Bot. 59: 206-216, 2007.

Banuls, J., Prmo-Millo, E.: Effect of salinity on some citrus scion-rootstock combinations. - Ann. Bot. 76: 97-102, 1995.

Bar, Y., Apfelbaum, A., Kafikafi, U., Goren, R.: Ethylene association with chloride stress in citrus plants. - Sci. Hortic. 73: 99-109, 1998.

Barrs, H.D., Weatherley, P.E.: A re-examination of the relative turgidity technique for estimating water deficits in leaves. Austr. J. Biol. Sci. 15: 413-428, 1962.

Bates, L.S., Waldren, R.P., Teare, I.D.: Rapid determination of free proline for water stress studies. - Plant Soil 39: 205-207, 1973.

Behboudian, M.H., Walker, R.R., Torokfalvy, E.: Effects of water stress and salinity on photosynthesis of pistachio. - Sci. Hortic. 29: 251-261, 1986.

Ben Ahmed, C., Ben Rouina, B., Boukhris, M.: Changes in water relations, photosynthetic activity and proline accumulation in one-year-old olive trees (Olea europaea L. cv. Chemlali) in response to $\mathrm{NaCl}$ salinity. - Acta Physiol. Plant. 30: 553-560, 2008.

Bhantana, P., Lazarovitch, N.: Evapotranspiration, crop coefficient and growth of two young pomegranate (Punica granatum L.) varieties under salt stress. - Agr. Water Manage. 97: 715-722, 2010.

Bilger, W., Schreiber, U., Lange, O.L.: Chlorophyll fluorescence as an indicator of heat induced limitation of photosynthesis in Arbutus unedo L. - In: Tenhunen, J.D., Catarino, F.M., Lange, O.L., Oechel, W.C. (ed.): Plant Response to Stress. Pp. 391399. Springer-Verlag, Berlin - Heidelberg - New York London - Paris - Tokyo 1987

Björkman, O., Demmig, B.: Photon yield of $\mathrm{O}_{2}$ evolution and chlorophyll fluorescence characteristics at $77 \mathrm{~K}$ among vascular plants of diverse origins. - Planta 170: 489-504, 1987.
Black, C.A.: Methods of Soil Analysis. Part I: Physical and mineralogical properties. American Society of Agronomy, Madison, Wisconsin, USA 1965.

Bohnert, H.J., Jensen, R.G.: Strategies for engineering water stress tolerance in plants. - Trends Biotech. 14: 89-97, 1996.

Bongi, G., Loreto, F.: Gas-exchange properties of salt-stressed olive (Olea europea L.) leaves. - Plant Physiol. 90: 1408-1416, 1989.

Chapman, H.D.: Diagnostic Criteria for Plants and Soils. Pp. 793. Division of Agricultural Science, University of California, Oakland, USA 1966.

Chapman, H.D., Pratt, P.F.: Methods of Analysis for Soils, Plants and Water. - Chapman Publisher, Riverside, CA, USA 1982.

Chaves, M.M., Flexas, J., Pinheiro, C.: Photosynthesis under drought and salt stress: regulation mechanisms from whole plant to cell. - Ann. Bot. 103: 551-560, 2009.

Chen Z., Cuin T.A., Zhou M., et al.: Compatible solute accumulation and stress-mitigating effects in barley genotypes contrasting in their salt tolerance. - J. Exp. Bot. 58: 4245-4255, 2007.

Cornic, G.: Drought stress and high light effects on leaf synthesis. - In: Baker, N.R., Bowyer, J.R. (ed.): Photoinhibition of Photosynthesis. From Molecular Mechanisms to the Field. Pp. 297-313. Bios Sci. Publ., Oxford 1994.

Dodd, I.C.: Hormonal interactions and stomatal responses. - J Plant Growth Regul. 22: 32-46, 2003.

Doring, J., Ludders, P.: Effect of different salt treatment on Punica granatum at different root temperatures. Gartenbauwissenschaf. 51: 92-96, 1986.

Doring, J., Ludders, P.: Influence of sodium salts on $\mathrm{Na}, \mathrm{Cl}$ and $\mathrm{SO}_{4}$ content in leaves, shoots and roots of Punica granatum.Gartenbauwissenschaf. 52: 26-31, 1987.

Estan, M.T., Martinez-Rodriguez, M.M., Perez-Alfocea, F., et $a l$ : Grafting raises the salt tolerance of tomato through limiting the transport of sodium and chloride to the shoot. - J. Exp. Bot. 56: 703-712, 2005 .

FAO: FAO Land and Plant Nutrition Management Service, 2008. Fernandez, R.T., Perry, R.L., Flore, J.A.: Drought response of young three apple trees on three rootstocks. II. Gas exchange, chlorophyll fluorescence, water relations, and leaf abscisic acid. - J. Am. Soc. Hortic. Sci. 122: 841-848, 1997.

Flexas, J., Bota, J., Loreto, F. et al.: Diffusive and metabolic limitations to photosynthesis under drought and salinity in $\mathrm{C}_{3}$ plants. - Plant Biol. 6: 269-279, 2004. 
Flowers, T.J., Troke, P.F., Yeo, A.R.: The mechanism of salt tolerance in halophytes. - Ann. Rev. Plant Physio. 28: 89-121, 1977.

Fricke, W., Akhiyarova, G., Veselov, D., Kudoyarova, G.: Rapid and tissue-specific changes in ABA and in growth rate response to salinity in barley leaves. - J. Exp. Bot. 55: 1115-1123, 2004.

Fricke, W., Peters, W.S.: The biophysics of leaf growth in saltstressed barley. A study at the cell level. - Plant Physiol. 129: 374-388, 2002.

García-Sánchez, F., Syvertsen, J.P.: Salinity tolerance of cleopatra mandarin and carrizo citrange rootstock seedlings is affected by $\mathrm{CO}_{2}$ enrichment during growth. - J. Am. Soc. Hortic. Sci. 131: 24-31, 2006.

Genty, B., Briantais, J.M., Baker, N.R.: The relationship between the quantum yield of photosynthetic electron transport and quenching of chlorophyll fluorescence. - Biochim. Biophys. Acta 990: 87-92, 1989

Glynn, C.P., Gillian, A.F., Gavin, O.: Foliar salt tolerance of Acer genotypes using chlorophyll fluorescence. - J. Arboricult. 29: 61-65, 2003.

Goreta, S., Bucević-Popović, V., Pavela-Vrancić, M., Perica, S.: Salinity-induced changes in growth, superoxide dismutase activity, and ion content of two olive cultivars. - J. Plant Nutr. Soil Sc. 170: 398-403, 2007.

Grattan, S.R., Grieve, C.M.: Salinity-mineral nutrient relations in horticultural crops. - Sci. Hortic. 78: 127-157, 1999.

Greenway, H., Munns, R.: Mechanisms of salt tolerance in nonhalophytes. - Ann. Rev. Plant Physio. 31: 149-190, 1980.

Hasegawa, P.M., Bressan, R.A., Zhu, J.K., Bohnert, H.J.: Plant cellular and molecular responses to high salinity. - Ann. Rev. Plant Physio. 51: 463-499, 2000.

Hernandez, J.A., Jimenez, A., Mullineaux, P., Sevilla, F.: Tolerance of pea (Pisum sativum L.) to a long term salt stress is associated with induction of antioxidant defenses. - Plant Cell Environ. 23: 853-862, 2000.

Hokmabadi, H., Arzani, K., Grierson, P.F.: Growth, chemical composition, and carbon isotope discrimination of pistachio (Pistacia vera L.) rootstock seedlings in response to salinity.Austr. J. Agr. Res. 56: 135-144, 2005.

Holland, D., Hatib, K., Bar-Yáakov, I.: Pomegranate: botany, horticulture, breeding. - In: Janick, J. (ed.): Horticultural Reviews, Vol. 35, Pp. 127-191, Wiley-BlackWell Publication. New Jersey 2009

Hu, Y.C., Fricke, W., Schmidhalter, U.: Salinity and the growth of non-halophytic grass leaves: the role of mineral nutrient distribution. - Funct. Plant Biol. 32: 973-985, 2005.

Hu, Y., Burucs, Z., Von Tucher, S., Schmidhalter, U.: Short-term effects of drought and salinity on mineral nutrient distribution along growing leaves of maize seedlings. - Environ. Exp. Bot. 60: 268-275, 2007.

Hunt, R.: Basic growth analysis: Plant Growth Analysis for Beginners. Pp. 112. Unwin Hyman, London, UK 1990.

Irigoyen, J.J., Emerich, D.W., Sanchez-Dias, M.: Water stress induced changes in concentrations of proline and total soluble sugars in nodulated alfalfa (Medicago sativa) plants. - Physiol. Plantarum 84: 55-60, 1992.

Jain, B.L., Dass, H.C.: Effect of saline water on pomegranate of sapling of jujube (Zizyphus mauritiana), Indian cherry (Cordia dichotoma var.Wallichi) and pomegranate (Punica granatum) at nursery stage. - Indian J. Agr. Sci. 58: 420-421, 1988.

Jimenez, M.S., Gonzalez-Rodriguez, A.M., Morales, D., et al.: Evaluation of chlorophyll fluorescence as a tool for salt stress detection in roses. - Photosynthetica 33: 291-301, 1997.
Jones, R.G.W., Storey, R., Leigh, R.A., et al.: A hypothesis on cytoplasmic osmoregulation. - In: Marre, E., Cifferi, O. (ed.): Regulation of Cell Membrane Activities in Plants. Pp. 121-136. Elsevier, Amsterdam 1977.

Juneau, P., Green, B.R., Harrison, P.J.: Simulation of PulseAmplitude-Modulated (PAM) fluorescence: Limitations of some PAM-parameters in studying environmental stress effects. - Photosynthetica 43: 75-83, 2005.

Kalaji, H.M., Govindjee, Bosa, K., et al.: Effects of salt stress on photosystem II efficiency and $\mathrm{CO}_{2}$ assimilation of two Syrian barley landraces. - Environ. Exp. Bot. 73: 64-72, 2011.

Karimi, E., Abdolzadeh, A., Saideghipour, H.R.: Increasing salt tolerance in olive, Olea europaea L. plants by supplemental potassium nutrition involves changes in ion accumulation and anatomical attributes. - Int. J. Plant Prod. 3: 49-60, 2009

Kaya, C., Higgs, D., Saltali, K., Gezeral, O.: Response of strawberry grown at high salinity and alkalinity to supplementary potassium. - J. Plant Nutr. 25: 1415-1427, 2002a.

Kaya, C., Kirnak, H., Higgs, D., Saltali, K.: Supplementary calcium enhances plant growth and fruit yield in strawberry cultivars grown at high $(\mathrm{NaCl})$ salinity. - Sci. Hortic. 93: 65$74,2002 b$.

Kempa, S., Krasensky, J., Dal Santo, S. et al.: A central role of abscisic acid in stress-regulated carbohydrate metabolism. PLOS ONE, doi: 10.1371/journal.pone.0003935, 2008.

Khaleghi, E., Arzani, K., Moallemi, N., Barzegar, M.: Evaluation of chlorophyll content and chlorophyll fluorescence parameters and relationships between chlorophyll a, b and chlorophyll content index under water stress in Olea europaea cv. Dezful. - World Acad. Sci. Engin. Tech. 68: 1154-1157, 2012

Khan M.H., Panda S.K.: Alterations in root lipid peroxidation and antioxidative responses in two rice cultivars under $\mathrm{NaCl}$ salinity stress. - Acta Physiol. Plant. 30: 81-89, 2008.

Khayyat, M., Vazifeshenas, M.R., Rajaee, S., Jamalian, S.: Potassium effect on ion leakage, water usage, fruit yield and biomass production by strawberry plants grown under $\mathrm{NaCl}$ stress. - J. Fruit Ornament. Plant Res. 17: 79-88, 2009a.

Khayyat, M., Rajaee, S., Sajjadinia, A., Eshghi, S., Tafazoli, E.: Calcium effects on changes in chlorophyll contents, dry weight and micronutrients of strawberry (Fragaria ananassa Duch.) plants under salt-stress conditions. - Fruits 64: 53-59, 2009b.

Khoshgoftarmanesh, A.H., Siadat, H.: Mineral nutrition of vegetables and horticultural crops in saline conditions. Tehran, Iran: Agricultural Ministry, Deputy of Horticulture. Pp. 87. 2002.

Kitajima, M., Butler, W.L.: Quenching of chlorophyll fluorescence and primary photochemistry in chloroplasts by dibromothymoquinone. - Biochim. Biophys. Acta 376: 105$115,1975$.

Krause, G.H., Vernotte, C., Briantais, J.M.:. Photoinduced quenching of chlorophyll fluorescence in intact chloroplasts and algae. Resolution into two components. - BBA-Bioenergetics 679: 116-124, 1982.

Krause, G.H., Weis, E.: Chlorophyll fluorescence as a tool in plant physiology. II. Interpretation of fluorescence signals. Photosynth. Res. 5: 139-157, 1984.

Lazár, D.: Chlorophyll a fluorescence induction. - BBABioenergetics 1412: 1-28, 1999.

Lazár, D., Nauš, J.: Statistical properties of chlorophyll fluorescence induction parameters. - Photosynthetica 35: 121-127, 1998.

Lazár, D., Sušila, P., Nauš, J.: Early detection of plant stress from 
changes in distributions of chlorophyll $a$ fluorescence parameters measured with fluorescence imaging. - J. Fluoresc. 16: 173-176, 2006.

Lawlor, D.W., Cornic, G.: Photosynthetic carbon assimilation and associated metabolism in relation to water deficits in higher plants. - Plant Cell Environ. 25: 275-294, 2002.

Levin, G.M.: Pomegranate roads: A Soviet botanist's exile from Eden. Pp. 15-183. Floreat Press, Forestville, USA 2006.

Lutts, S., Kinet, J.M., Bouharmont, J.: Changes in plant response to $\mathrm{NaCl}$ during development of rice (Oryza sativa $\mathrm{L}$.) varieties differing in salinity resistance. - J. Exp. Bot. 46: 1843-1852, 1995.

Lutts, S., Kinet, J.M., Bouharmont, J.: NaCl-induced senescence in leaves of rice (Oryza sativa L.) cultivars differing in salinity resistance. - Ann. Bot.-London 78: 389-398, 1996.

Mane, A.V., Deshpande T.V., Wagh V.B., Karadge B.A., Samant J.S.: A critical review on physiological changes associated with reference to salinity. - Int. J. Environ. Sci. 1: 1192-1216, 2011

Mansour, M.M.F., Salama, K.H.A.: Cellular basis of salinity tolerance in plants. - Environ. Exp. Bot. 52: 113-122, 2004.

Marschner, H.: Mineral Nutrition of Higher Plants. $2^{\text {nd }}$ Ed. Pp.892. Academic Press Ltd., London 1995.

Martinez-Rodriguez, M.M., Estañ, M.T., Moyano, E., et al.: The effectiveness of grafting to improve salt tolerance in tomato when an 'excluder' genotype is used as scion. - Environ. Exp. Bot. 63: 392-401, 2008.

Matos, M.C., Rebelo, E., Lauriano, J., et al.: $\mathrm{CO}_{2}$ assimilation and water relations of almond tree (Prunus amygdalus Batsch) cultivars grown under field conditions. - Photosynthetica 42: 473-476, 2004.

Meinander, O., Somersalo, S., Holopainen, T., Strasser, R.J.: Scots pines after exposure to elevated ozone and carbon dioxide probed by reflectance spectra and chlorophyll $a$ fluorescence transients. - J. Plant Physiol. 148: 229-236, 1996.

Melcher, K., Ng, L.M., Zhou, X.E. et al.: A gate-latch-lock mechanism for hormone signalling by abscisic acid receptors. - Nature 462: 602-608, 2009.

Molinari, H.B.C., Marur, C.J., Daros, E., et al.: Evaluation of the stress-inducible production of proline in transgenic sugarcane (Saccharum spp.): osmotic adjustment, chlorophyll fluorescence and oxidative stress. - Physiol. Plantarum 130: 218-229, 2007.

Munns, R.: Genes and salt tolerance: bringing them together. New Phytol. 167: 645-663, 2005.

Munns, R., Guo, J., Passioura, J.B., Cramer, G.R.: Leaf water status controls day-time but not daily rates of leaf expansion in salt-treated barley. - Aust. J. Plant Physiol. 27: 949-957, 2000.

Munns, R., James, R.A., Läuchli, A.: Approaches to increasing the salt tolerance of wheat and other cereals. - J. Exp. Bot. 57: 1025-1043, 2006.

Munns, R., Tester M.: Mechanisms of salinity tolerance. - Annu. Rev. Plant Biol. 59: 651-681, 2008.

Naeini, M.R., Khoshgoftarmanesh, A.H., Fallahi, E.: Partitioning of chlorine, sodium, and potassium and shoot growth of three pomegranate cultivars under different levels of salinity. - J. Plant Nutr. 29: 1835-1843, 2006.

Neocleous, D., Vasilakakis, M.: Effects of $\mathrm{NaCl}$ stress on red raspberry (Rubus idaeus L. 'Autumn Bliss'). - Sci. Hortic.Amsterdam 112: 282-289, 2007.

Nuccio, M.L., Rhodes, D., McNeil, S.D., Hanson, A.D.: Metabolic engineering of plants for osmotic stress resistance.Curr. Opin. Plant Biol. 2: 128-134, 1999.

Oliveira Medici, L., Antunes Azevedo, R., Pasqualoto Canellas,
L. et al.: Stomatal conductance of maize under water and nitrogen deficits. - Pesqui. Agropecu. Bras. 42: 599-601, 2007.

Paranychianakis, N.V., Angelakis, A.N.: The effect of water stress and rootstock on the development of leaf injuries in grapevines irrigated with saline effluent. - Agr. Water Manage. 95: 375-382, 2008.

Patil, V.K., Waghmare, P.R.: Salinity tolerance of pomegranate. - J. Maharashtra Agric. Univ. 7: 268-269, 1982.

Percival, G.C., Fraser, G.A.: Measurement of the salinity and freezing tolerance of Crataegus genotypes using chlorophyll fluorescence. - J. Arboricult. 27: 223-245, 2001.

Perica, S., Goreta, S., Selak, G.V.: Growth, biomass allocation and leaf ion concentration of seven olive (Olea europaea L.) cultivars under increased salinity. - Sci. Hortic.-Amsterdam 117: 123-129, 2008

Petsas, A., Grammatikopoulos, G.: Drought resistance and recovery of photosystem II activity in a Mediterranean semideciduous shrub at the seedling stage. - Photosynthetica 47: 284-292, 2009.

Prior, L.D., Grieve, A.M., Bevington, K.B., Slavich, P.G.: Longterm effects of saline irrigation water on 'Valencia' orange trees: relationships between growth and yield, and salt levels in soil and leaves. - Aust. J. Agr. Res. 58: 349-358, 2007.

Ranjbar, V.: Genetic and geographical variation, revival principals, rolls and evolution of pomegranate. - Saveh Agric. Res. Stat. Tech. J. 3: 15-28, 1981.

Ranjbarfordoei, A., Samson, R., Van Damme, P.: Chlorophyll fluorescence performance of sweet almond [Prunus dulcis (Miller) D. Webb] in response to salinity stress induced by NaCl. - Photosynthetica 44: 513-522, 2006.

Roades, J.D.: Soluble salts. - In: Page, A.L. et al. (ed.): Methods of Soil Analysis, 2 ${ }^{\text {nd }}$ ed., Part 2, Pp. 167-179, 1982.

Rhodes, D., Nadolska-Orczyk, A., Rich, P.J.: Salinity, osmolytes and compatible solutes. - In: Läuchli, A., Lüttge, U. (ed.): Salinity, Environment-Plants-Molecules. Pp. 181-204. Springer, Dordrecht 2002.

Roháček, K.: Chlorophyll fluorescence parameters: the definitions, photosynthetic meaning, and mutual relationships. - Photosynthetica 40: 13-29, 2002.

Rouhi, V., Samson, R., Lemeur, R., Van Damme, P.: Photosynthetic gas exchange characteristics in three different almond species during drought stress and subsequent recovery. - Environ. Exp. Bot. 59: 117-129, 2006.

Sabra, A., Daayf, F., Renault, S.: Differential physiological and biochemical responses of three Echinacea species to salinity stress. - Sci. Hortic.-Amsterdam 135: 23-31, 2012.

Saini, R.S., Sharme, K.D., Dhankhar, O.P., Kaushik, R.A.: Laboratory manual of analytical techniques in horticulture. Pp. 49-50. Agrobios, India 2001.

Sairam, R.K., Tyagi, A.: Physiology and molecular biology of salinity stress tolerance in plants. - Curr. Sci. India 86: 407421, 2004.

Sergio, L., De Paola, A., Cantore, V., et al.: Effect of salt stress on growth parameters, enzymatic antioxidant system, and lipid peroxidation in wild chicory (Cichorium intybus L.). - Acta Physiol. Plant. 34: 2349-2358, 2012.

Silva-Ortega, C.O., Ochoa-Alfaro, A.E., Reyes-Aguerro, J.A., et al.: Salt stress increases the expression of $p 5 c s$ gene and induces proline accumulation in cactus pear. - Plant Physiol. Bioch. 46: 82-92, 2008.

Singh, A.K., Dubey, R.S.: Changes in chlorophyll $a$ and $b$ contents and activities of photosystems 1 and 2 in rice seedlings induced by $\mathrm{NaCl}$. - Photosynthetica 31: 489-499, 1995. 
Sivstev, M.V., Ponamareva, S.V., Kuzmetsova, E.A.: Effect of salinization and herbicide on chlorophyllase activity in tomato leaves. - Fiziol. Biokh. Kult. Rast. 20: 62-65, 1973.

Smekens, M.J., Vantienderen, P.H.: Genetic variation and plasticity of Plantago coronopus under saline conditions. Acta Oecol. 22: 187-200, 2001.

Tester, M., Davenport, R.J.: $\mathrm{Na}^{+}$transport and $\mathrm{Na}^{+}$tolerance in higher plants. - Ann. Bot. 91: 503-527, 2003.

Tiwari, J.K., Munshi, A.D., Kumar, R., et al.: Effect of salt stress on cucumber: $\mathrm{Na}^{+} / \mathrm{K}^{+}$ratio, osmolyte concentration, phenols and chlorophyll content. - Acta Physiol. Plant. 32: 103-114, 2010.

Torrecillas, A., Guillaume, C., Alarcón, J.J., Ruiz-Sanchez, M.C.: Water relations of two tomato species under water stress and recovery. - Plant Sci. 105: 169-176, 1995.

Varasteh, F., Arzani, K., Zamani, Z., Mohseni, A.: Evaluation of the most important fruit characteristics of some commercial pomegranate (Punica granatum L.) cultivars of Iran. - Acta Hortic. 818:103-108, 2009.

Wahome, P.K.: Mechanisms of salt $(\mathrm{NaCl})$ stress tolerance in horticultural crops - a mini review. - Acta Hortic. 609: 127131, 2003.

Weber, J., Reimann-Phillip, R.: Influence of $\mathrm{NaCl}$ and $\mathrm{NaHCO}_{3}$ on the foliage and pollen germination of rose rootstock plants grown in Mitscherlich pots. - Acta Hortic. 246: 353-354, 1989.

Yordanov, I., Tsonev, T., Goltsev, V., Kruleva, L., Velikova, V.: Interactive effect of water deficit and high temperature on photosynthesis of sunflower and maize plants. 1. Changes in parameters of chlorophyll fluorescence induction kinetics and fluorescence quenching. - Photosynthetica 33: 391-402, 1997.

Zaman, B., Arshad, A., Salim, M., Khawer, H.: Growth of wheat as affected by sodium chloride and sodium sulphate salinity. Pakistan J. Biol. Sci. 5: 1313-1315, 2002.

Zhang, H.B., Xu, D.Q.: Role of light-harvesting complex 2 dissociation in protecting the photosystem 2 reaction centres against photodamage in soybean leaves and thylakoids. Photosynthetica 41: 383-391, 2003.

Zhu, J.: Regulation of ion homeostasis under salt stress. - Curr. Opin. Plant Biol. 6: 441-444, 2003. 